\title{
Battery State of Health and Charge Estimation Using Machine Learning Methods
}

\author{
Enes Malik Şahin ${ }^{*}$, Savaş Şahin $^{2}$, İbrahim Tanağardıgil ${ }^{3}$ \\ 1* İzmir Katip Çelebi University, Faculty of Engineering and Architecture, Departmant of Electrical Electronics Engineering, İzmir, Turkey, (ORCID: 0000-0001-5458- \\ 0467), enesmlk314@gmail.com \\ 2 İzmir Katip Çelebi University, Faculty of Engineering and Architecture, Departmant of Electrical Electronics Engineering, İzmir, Turkey, (ORCID: 0000-0003-2065- \\ 6907), sahin.savas@yahoo.com \\ ${ }^{3}$ Tescom Sanayi ve Ticaret A.Ş. Ar-Ge Bölümü, İzmir, Türkiye (ORCID: 0000-0002-5977-6482), ibrahim.tanagardigil@gmail.com
}

(3rd International Congress on Human-Computer Interaction, Optimization and Robotic Applications June 11-13, 2021)

(DOI: $10.31590 /$ ejosat.959630)

ATIF/REFERENCE: Şahin, E., Şahin, S., \& Tanağardıgil, İ. (2021). Battery State of Health and Charge Estimation Using Machine Learning Methods. European Journal of Science and Technology, (26), 389-394.

\begin{abstract}
In this study, state of health (SOH) and state of charge (SOC) estimation of series connected batteries were evaluated for their charge and discharge durations. For this purpose, an ARM-based electronics card module was developed for observing instantaneous batteries voltage, current and temperature values during the charge and discharge process. The implemented microcontroller based card module gathers data from the current, voltage, and temperature sensors and it transfers to the computer environment via serial communication port. A specific human machine interface is designed via app-designer. The obtained variables were used for estimating regression models of the machine-learning toolbox. Random forest, decision tree, polynomial, extreme gradient boosting, linear and gradient boosting regression models were used for instantaneous SOH and SOC estimation for batteries during the chargedischarge period. Root Mean Square Error (RMSE) and $R^{2}$ score results were used for performance evaluation of regression models. When the RMSE and $R^{2}$ score results were compared, the decision tree regression model was the regression model that made the most accurate SOH and SOC estimation and the results were presented.
\end{abstract}

Keywords: State of Charge, State of Health, Microprocessor, Machine learning, Regression models.

\section{Makina Öğrenmesi Metotları Kullanılarak Batarya Sağlık ve Şarj Durumunun Kestirimi}

$\ddot{O} z$

$\mathrm{Bu}$ çalışmada, seri bağlı pillerin sağlık durumu (SOH) ve şarj durumu (SOC) tahminleri şarj ve deşarj süreleri boyunca değerlendirilmiştir. Bu amaçla, şarj ve deşarj işlemi sırasında anlık akü voltajı, akım ve sıcaklık değerlerini gözlemlemek için ARM tabanlı bir elektronik kart modülü geliştirilmiştir. Uygulanan mikrodenetleyici tabanlı kart modülü akım, gerilim ve sıcaklık sensörlerinden verileri toplayarak seri haberleşme portu üzerinden bilgisayar ortamına aktarır. App-designer aracılığı ile belirli bir insan makine arayüzü tasarlanmıştır. Elde edilen değişkenler kullanılarak kestirim yapmak için, makine öğrenimi araç kutusunun regresyon modelleri kullanılır. Bataryalar için şarj-deşarj süresi boyunca anlık SOH ve SOC tahminlemesinin yapılması için, rasgele orman, karar ağacı, polinom, aşırı gradyan artırma, doğrusal ve gradyan artırıcı regresyon modelleri kullanıldı. Regresyon modellerinin performans değerlendirmesi için Kök Ortalama Kare Hatası (RMSE) ve $R^{2}$ skor sonuçları kullanılmıştır. RMSE ve $R^{2}$ skor sonuçları karşılaştırıldığında, karar ağacı regresyon modeli en doğru SOH ve SOC kestirim yapan regresyon modeli olmuştur ve sonuçlar sunulmuştur.

Anahtar Kelimeler: Şarj Durumu, Sağlık Durumu, Mikroişlemci, Makine Öğrenmesi, Regresyon modelleri

\footnotetext{
*Corresponding Author: $\underline{x x x @ x x x . x x . x x}$
} 


\section{Introduction}

Series connected battery packs are used as energy storage systems (ESS) for electrical devices such as booster converters, uninterruptible power supply (UPS) and electric vehicle (EV) systems (Yu, 2013), (Badeda, 2018), (Hannan, 2017). In order to fully exploit the potential of the battery in ESS, the system might be properly charged and discharged, which is achieved by accurately measuring the state of charge (SOC) and state of health (SOH) (Cacciato, 2016). After the obtained these variables, regression models of machine learning toolboxes were used to estimate $\mathrm{SOH}$ and SOC models. So, these regression models are used to examine the estimated and real SOC and $\mathrm{SOH}$ values by using dependent and independent variables (Fahrmeir, 2013).

In this study, SOC and SOH values of series connected batteries were evaluated instantaneously during the charging and discharging periods. The considered serial connected batteries were assessed with 12V-7A lead-acid battery containing 6 leadacid cells (Gu, 1987), (Yiğit Akü, 2021).. The developed system includes an ARM based development board, sensors, a relay and non-inverting amplifier circuits. To gather the voltage variables of the batteries, the analog to digital converter (ADC) and interintegrated circuit ports were used. Likewise, to obtain the temperature and current variables of the batteries, universal synchronous asynchronous receiver transmitter (USART) serial communication protocol is used and it also provides transferring the all obtained data to the computer environment (Brown, G.,2012). The obtained data were analyzed using random forest, decision tree, polynomial, extreme gradient boosting, linear and gradient boosting regression models. RMSE and $R^{2}$ score results were used for performance evaluation of the estimated regression models. According to the performance evaluation results, the best model was the decision tree regression model. Moreover, a specific human machine interface (HMI) has been designed through App-Designer (Valle, 2017).

The following sections are as follows; in the second section, the developed module, obtained data results and regression models are explained. In the third section, the estimation results of the data are compared using models. In the last section, the results are presented.

\section{Material and Method}

\subsection{Developed Module}

The developed module consists of 3 ARM-based microprocessors, 3 serially connected batteries, 1 relay, 1 current sensor, 3 temperature sensors, 3 non-inverting amplifier circuits, 7 USB-TTL modules and 1 computer (Fig.1). The primary microprocessor as master processor is connected to the relay circuit for controlling the charge and discharge processes of the ESS. The primary microprocessor receives the measured voltage, current and temperature variables values. The received these data is sent to the computer environment by using the USART protocol with the related module.

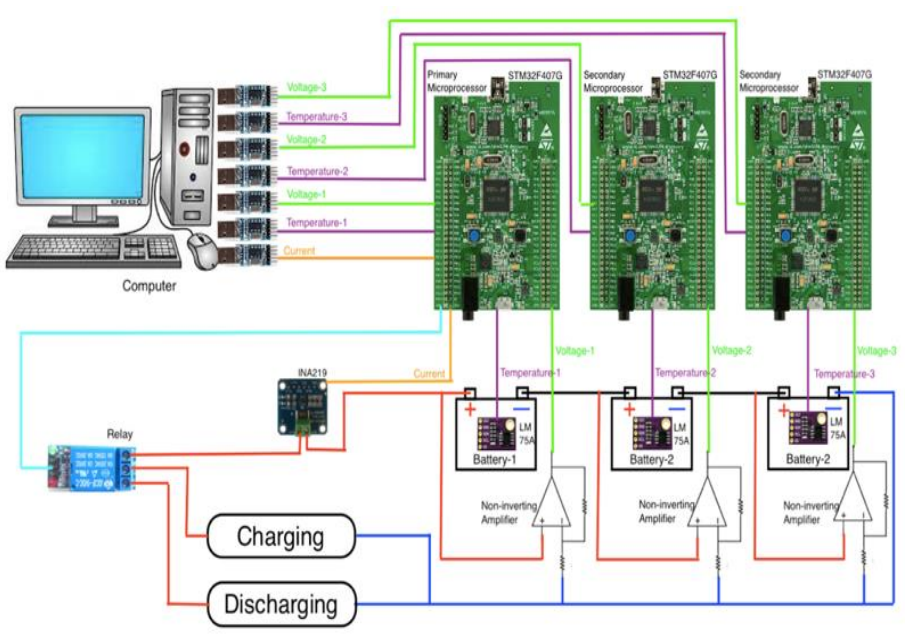

Figure 1. The developed module

The developed module is implemented in Fig.2 where INA219 current sensor is used with the $I^{2} C$ communication protocol. The current value is determined as in the range of \pm 3.2A with $1 \%$ accuracy (El Hadi, 2021). LM75A temperature sensor is used for the range of $-55^{\circ} \mathrm{C} \sim 125^{\circ} \mathrm{C}$ with an accuracy of $\pm 0.125^{\circ} \mathrm{C}$ (Stanimirescu, 2020). The voltages values are gathered with ADC ports and voltage scaling circuit implementing with non-inverting amplifiers for the 32bit ARM microcontroller (Brown, G.,2012). The flow chart of the developed system is given in Fig.3 where the voltage, current, and temperature values are obtained and they are sent to the computer environment. In Fig.4, the designed HMI displays $\mathrm{SOH}$ and SOC estimation results, along with graphs of data received from microprocessors (Valle, 2017).

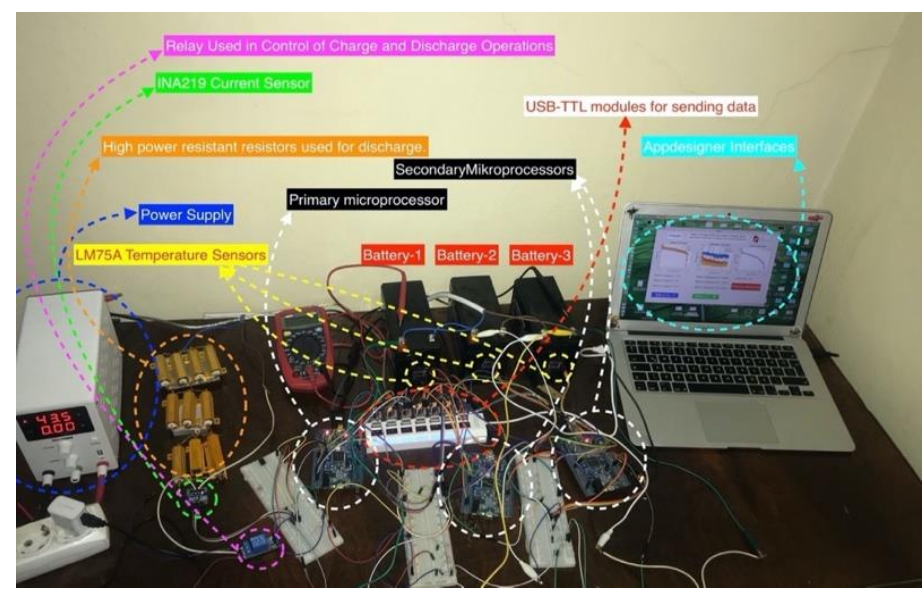

Figure. 2. The implemented system overview 


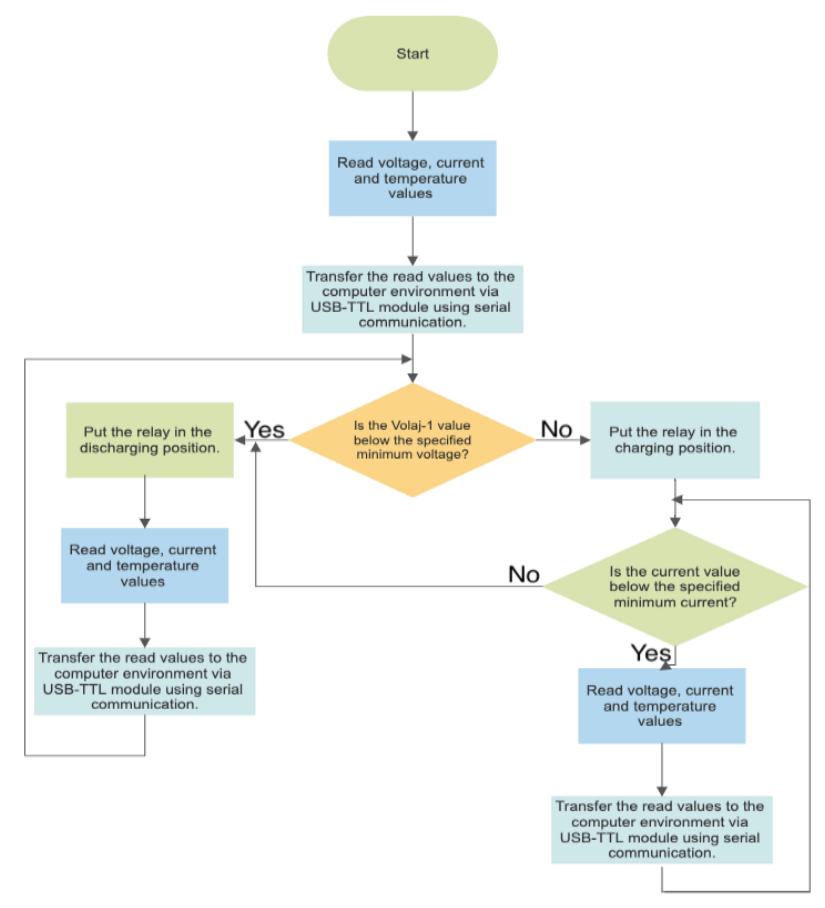

Figure 3. Flow chart of the algorithm

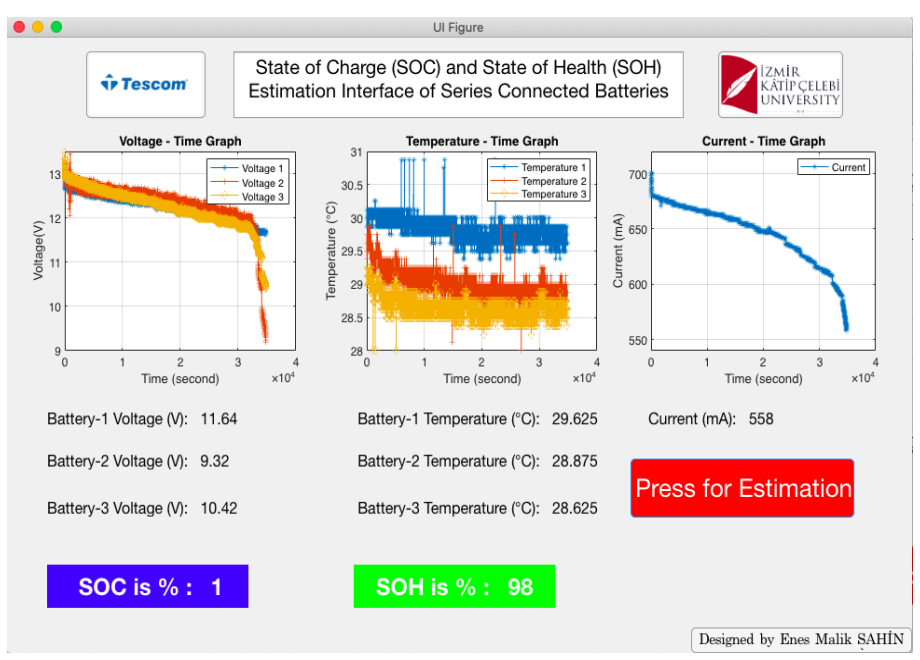

Figure 4. The designed HMI

After completing the experiments, the obtained charging voltage values of the ESS batteries are depicted in Fig.5. It is observed that the voltage value of each battery is approximately equal to each other during the charging period. In Fig.6, it is observed that the temperature values are presented during the charging period and their values are nearly same for each battery. According to the Fig.6d, the total current value of the system is observed as $700 \mathrm{~mA}$ for 2800 seconds. After 3200 seconds, it might be assumed as discharging initial conditions, the voltage value of battery decreases faster than the other two batteries. This situation might be explained that the voltage value of the battery- 1 is 11.51 volts, the voltage value of the battery- 2 is 9.28 volts and the voltage value of the battery-3 is 10.47 volts (Fig.7). However, in Fig. 8 during the discharge period, the temperature values are approximately the same as for each battery. According to Fig. 8d, the current value of the discharge period decreases according to the decrease in battery voltages since constant resistance is used.

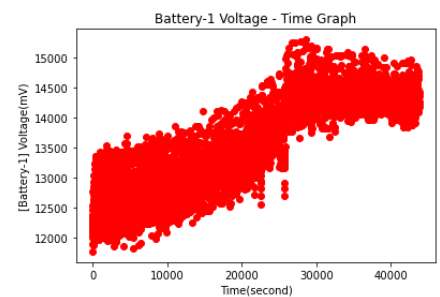

(a)

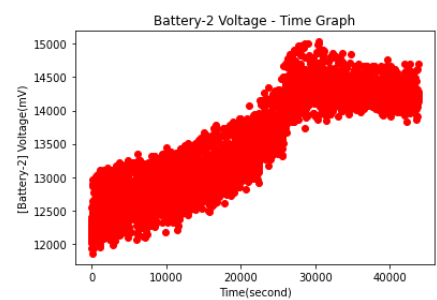

(b)

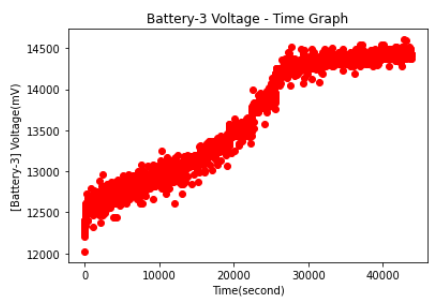

(c)

Figure 5. Charge voltage for a)battery-1, b)battery-2, c)battery-3

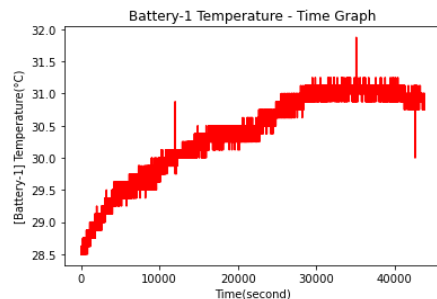

(a)

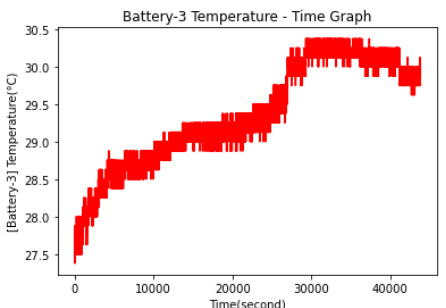

(c)

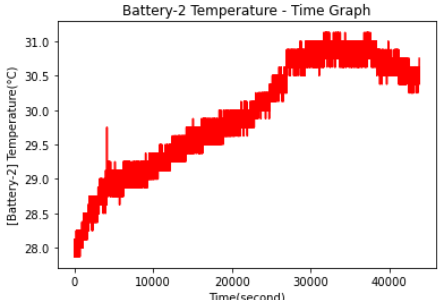

(b)

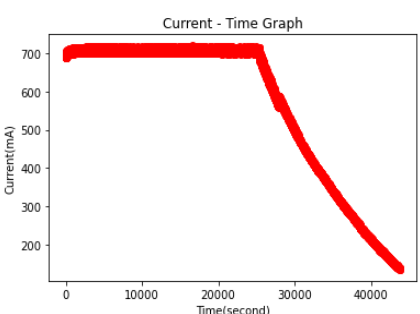

(d)
Figure 6. During charging process a) battery-1temperature, b) battery- 2 temperature, c) battery- 3 temperature, d) current

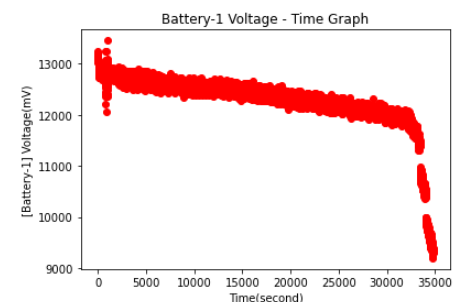

(a)

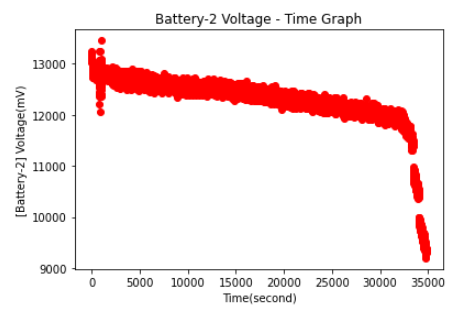

(b)

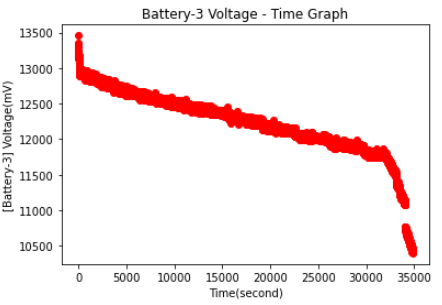

(c)

Figure 7. Discharge voltage for a) battery-1, b) battery-2, c) battery-3 


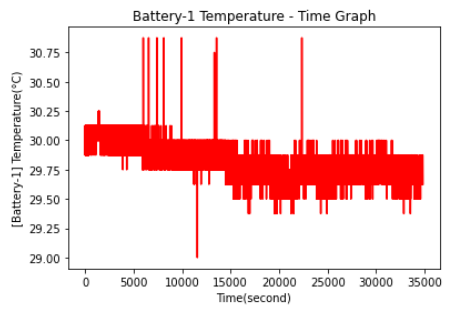

(a)

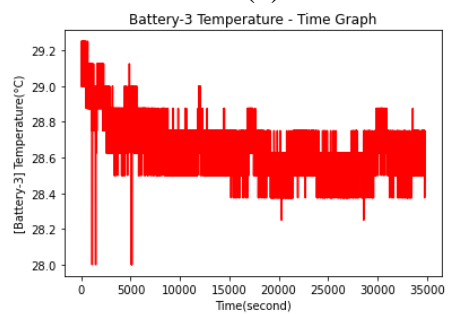

(c)

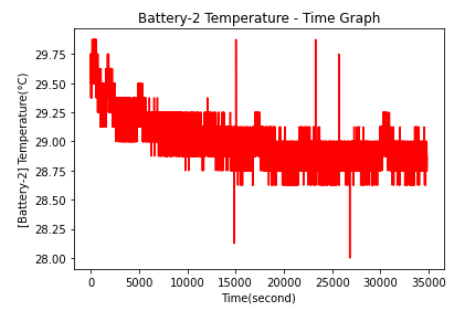

(b)

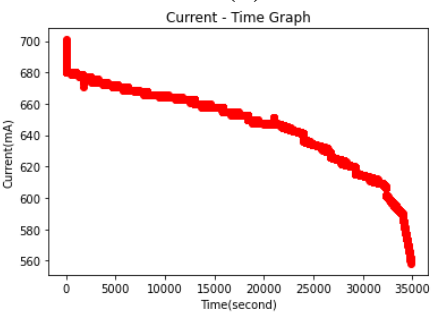

(d)
Figure 8. During discharge process a) battery-1temperature, b) battery-2 temperature, c) battery- 3 temperature, $d$ ) current

\subsection{Regression Models}

Machine learning algorithms fall into two groups: supervised learning and unsupervised learning (Freedman, 2009). Regression models are in the supervised learning group and are used to predict the relationship between dependent and independent variables in a function. Regression model analysis provides both predicting and estimating of the variables (Mason, 1991). Random forest regression, decision tree regression, polynomial regression are some of the regression models. In this project, regression models are used to estimate SOC and $\mathrm{SOH}$ of series connected batteries.

\section{Results and Discussion}

The voltage, current and temperature values obtained from series connected batteries were used for regression models. SOC and $\mathrm{SOH}$ estimations were assessed with six different regression models. The regression models used in this study; random forest regression ( $\mathrm{Pal}, 2005)$, decision tree regression, polynomial regression, linear Regression, extreme gradient boosting (XGB) Regression and Gradient Boosting Regression (Freedman, 2009). Using these regression models, the time variable during the charge and discharge application was estimated and SOC and $\mathrm{SOH}$ were estimated with this estimation. RMSE score and $R^{2}$ score were used to evaluate the regression models.

$$
\begin{aligned}
& R M S E=\sqrt[2]{\frac{\sum_{i=1}^{n}\left(y_{i}-\dot{y}\right)^{2}}{n}} \\
& R^{2}=1-\left(\frac{\sum_{i=1}^{n}\left(y_{i}-\dot{y}\right)^{2}}{\sum_{i=1}^{n}\left(y_{i}-\overline{\bar{y}}\right)^{2}}\right)
\end{aligned}
$$

The $y_{i}$ value in Equations (1) and (2) is the time variable, $\dot{y}$ is the predicted time variable, $\overline{\bar{y}}$ is the average of the time variable, and $n$ is the number of data obtained.

\subsection{SOC Estimation}

SOC estimation was made by the total power value of the three batteries in order to find the regression models by these power values of the three batteries obtained during the discharge e-ISSN: 2148-2683
(Fig.9) and charge (Fig.10) process. The error of the SOC estimation during charging was higher than the error of the SOC estimation during discharge. According to the RMSE score and $\mathrm{R}^{2}$ score values in Table- 1 and Table-2, decision tree regression is the most appropriate model.

Table 1. RMSE and $\mathrm{R}^{2}$ score values of regression models for discharge.

\begin{tabular}{|c|c|c|}
\hline Regression Models & RMSE Score & $\boldsymbol{R}^{\mathbf{2}}$ Score \\
\hline Random Forest Regression & 388.9697 & 0.998529 \\
\hline Decision Tree Regression & 27.9125 & 0.999992 \\
\hline Polinomial Regression & 474.8788 & 0.997791 \\
\hline Linear Regression & 2980.0720 & 0.913029 \\
\hline XGB Regression & 732.6739 & 0.994730 \\
\hline Gradient Boosting Regression & 708.3919 & 0.995120 \\
\hline
\end{tabular}

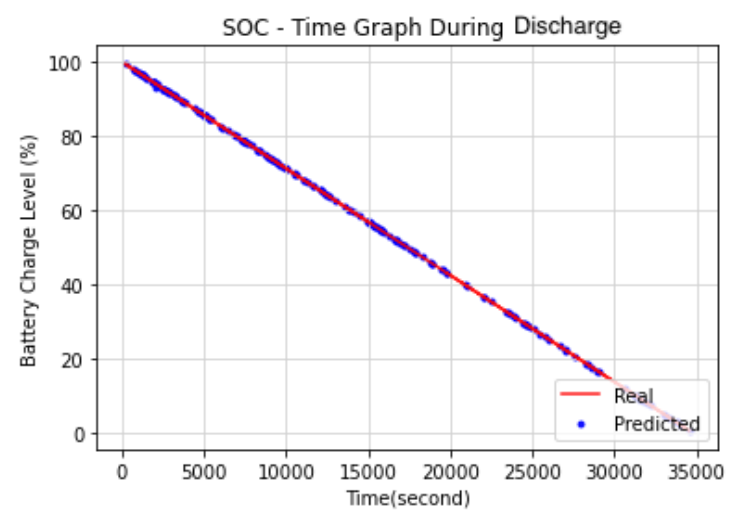

Figure 9. SOC during discharge.

Table 2. RMSE and $\mathrm{R}^{2}$ score values of regression models for charge

\begin{tabular}{|c|c|c|}
\hline Regression Models & RMSE Score & $\boldsymbol{R}^{\mathbf{2}}$ Score \\
\hline Random Forest Regression & 1367.8962 & 0.988368 \\
\hline Decision Tree Regression & 1332.2522 & 0.988972 \\
\hline Polinomial Regression & 1598.9724 & 0.984234 \\
\hline Linear Regression & 2619.0182 & 0.957703 \\
\hline XGB Regression & 1379.6596 & 0.988581 \\
\hline Gradient Boosting Regression & 1356.5291 & 0.988603 \\
\hline
\end{tabular}

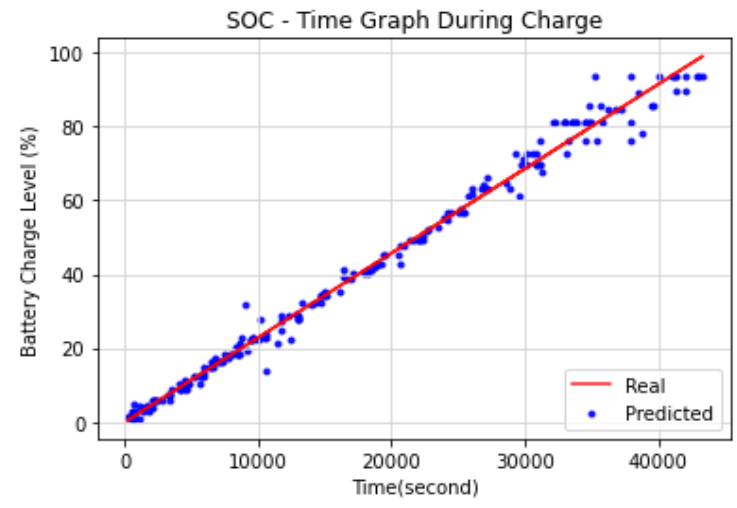

Figure 10. SOC during charge. 


\subsection{SOH Estimation}

SOH estimate was calculated using the time dependent change of the SOC estimate for both charge (3) and discharge (4) in the following equations;

$$
\begin{aligned}
& \operatorname{SOH}(\%)=\left(\frac{\text { time }_{\text {SOC(initial predicted })}-\text { time }_{\text {SOC }(\text { final real })}}{\text { time }_{\text {SOC }(\text { initial predicted })}-\text { time }_{\text {SOC }(\text { final predicted })}}\right) \times 100 \\
& \operatorname{SOH}(\%)=\left(\frac{\text { time }_{\text {SOC(final real })}-\text { time }_{\text {SOC }(\text { initial predicted })}}{\text { time }_{\text {Soc }(\text { final predicted })}-\text { time }_{\text {SOC }(\text { initial predicted })}}\right) \times 100
\end{aligned}
$$

where time $_{S O C \text { (initial predicted) }}$ is time(second) of the first predicted SOC value based on the values taken, time $_{\text {SOC (final real) }}$ is time(second) of the last SOC value

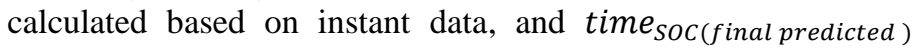
represents the time(second) value of the instantaneous SOC value on the predicted SOC-Time graph for the first charge / discharge period. SOH estimation results for charge and discharge in the first experiment are given in Fig.11 and Fig.12. Minimum time of 20000 seconds is required to calculate the $\mathrm{SOH}$ estimate with a minimum error of $5 \%$ during the charging process. By using the developed system, 6 charge and discharge experiments have been carried out. The average $\mathrm{SOH}$ results calculated as a result of the experiment are given in Table 3.

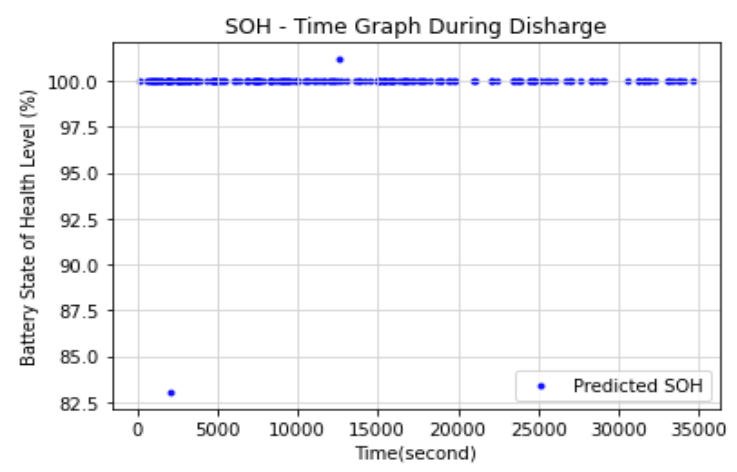

Figure 11. SOH - time graph while discharge

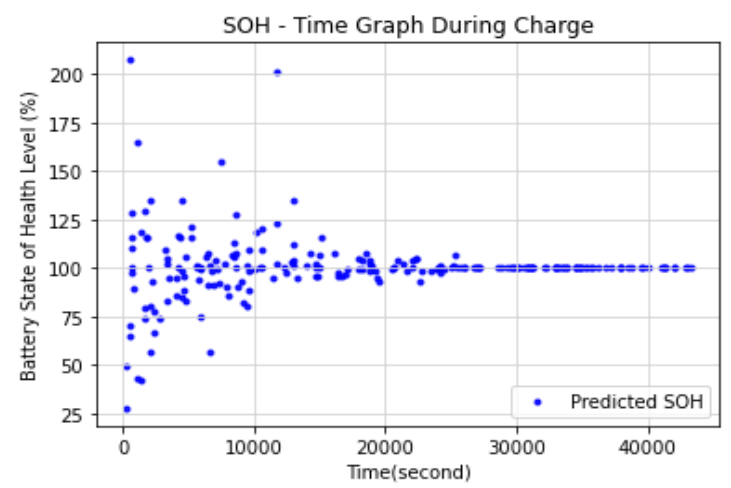

Figure 12. SOH - time graph while charge

Table 3. Average SOH results calculated in charge and discharge experiments

\begin{tabular}{|c|c|c|c|c|c|c|}
\hline $\begin{array}{c}\text { Average } \\
\text { SOH } \\
\text { Estimation }\end{array}$ & Exp.1 & Exp.2 & Exp.3 & Exp.4 & Exp.5 & Exp.6 \\
\hline $\begin{array}{c}\text { For } \\
\text { Charge }\end{array}$ & 99.9 & 100.0 & 99.9 & 99.8 & 100.0 & 99.7 \\
\hline $\begin{array}{c}\text { For } \\
\text { Disharge }\end{array}$ & 100.3 & 100.7 & 100.2 & 99.1 & 99.9 & 100.2 \\
\hline
\end{tabular}

In addition, Equation 5 is used to learn how long after the discharge period will be completed. The SOC and SOH values in this equation are the values estimated instantaneously using the regression model. The time (second) $($ when $\mathrm{SOH}=\% 100)$ value represents the first discharge time, that is the time calculated when the $\mathrm{SOH}$ value is $100 \%$ (in this study, the time (second) $)_{(\text {when } \mathrm{SOH}=\% 100)}$ value was calculated as 34800 seconds).

$$
\begin{aligned}
& \text { Discharge Completion Time }(\text { second })= \\
& \frac{\text { SOC }}{100} x \frac{\text { SOH }}{100} x \text { time }(\text { second })_{(\text {when } \text { SOH }=\% 100)}
\end{aligned}
$$

\section{Conclusions and Recommendations}

This study was developed for ECC application where serially connected battery sets are used to ensure the long life of these batteries by using SOC and $\mathrm{SOH}$ values during charge and discharge periods. The obtained regression models were made of the voltage, current and temperature measurements. The regression model performances for the SOC estimation were determined by RMSE and $R^{2}$ score values, and the decision tree regression model provided the best result.

\section{Acknowledge}

This work is supported by the Scientific and Technical Research Council of Turkey (TUBITAK) under 2209B Research Project Support Programme for Undergraduate Students with project number 1139B412001117.

\section{References}

Badeda, Julia, Monika Kwiecien, Dominik Schulte, and Dirk Uwe Sauer. "Battery state estimation for lead-acid batteries under float charge conditions by impedance: Benchmark of common detection methods." Applied Sciences 8, no. 8 (2018): 1308

Brown, G. (2012). Discovering the STM32 microcontroller. Cortex, 3, 34

Cacciato, M., Nobile, G., Scarcella, G., \& Scelba, G. (2016). Real-time model-based estimation of SOC and SOH for energy storage systems. IEEE Transactions on Power Electronics, 32(1), 794-803.

El Hadi, M., Ouariach, A., Essaadaoui, R., El Moussaouy, A., \& Mommadi, O. (2021). RC time constant measurement using an INA219 sensor: creating an alternative, flexible, low-cost configuration that provides benefits for students and schools. Physics Education, 56(4), 045015.

Fahrmeir, L., Kneib, T., Lang, S., \& Marx, B. (2013). Regression models. In Regression (pp. 21-72). Springer, Berlin, Heidelberg.

Freedman, D.A., (2009), Statistical Models: Theory and Practice. Cambridge University Press. ISBN 978-1-13947731-4.

Hannan, Mohammad A., MS Hossain Lipu, Aini Hussain, and Azah Mohamed. "A review of lithium-ion battery state of 
charge estimation and management system in electric vehicle applications: Challenges and recommendations." Renewable and Sustainable Energy Reviews 78 (2017): 834854.

Stanimirescu, A., Egri, A., Soica, F. F., \& Radu, S. M. (2020). Measuring the change of air temperature with 8 LM75A sensors in mining area. In MATEC Web of Conferences (Vol. 305, p. 00046). EDP Sciences.

Valle, J. M. G., García, J. C. C., \& Cadaval, E. R. (2017, May). Electric vehicle monitoring system by using MATLAB/App Designer. In 2017 International Young Engineers Forum (YEF-ECE) (pp. 65-68). IEEE.

Yiğit Akü. (2021), [online] Available: https://www.yigitaku.com/wp-content/uploads/2016/12/YD12-7-AH_AGM-brosur.pdf

Yu, Li-Ren, Yao-Ching Hsieh, Wei-Chen Liu, and Chin-Sien Moo. "Balanced discharging for serial battery power modules with boost converters." In 2013 International Conference on System Science and Engineering (ICSSE), pp. 449-453. IEEE, 2013. 